Article

\title{
How Do Conservation and the Tourism Industry Affect Local Livelihoods? A Comparative Study of Two Nature Reserves in China
}

\author{
Weiye Wang ${ }^{1}$, Jinlong Liu ${ }^{2, *}$, Robert Kozak ${ }^{1}$, Mengmeng Jin ${ }^{2}$ and John L. Innes ${ }^{1}$ \\ 1 Faculty of Forestry, University of British Columbia, 2424 Main Mall, Vancouver, BC V6T 1Z4, Canada; \\ wwywangweiye@gmail.com (W.W.); rob.kozak@ubc.ca (R.K.); john.innes@ubc.ca (J.L.I.) \\ 2 School of Agricultural Economics and Rural Development, Renmin University of China, Mingde Building, \\ No. 59 Zhongguancun Street, Beijing 100872, China; jinmengmeng6435@163.com \\ * Correspondence: liujinlong@ruc.edu.cn; Tel.: +86-10-8250-9118
}

Received: 27 April 2018; Accepted: 2 June 2018; Published: 8 June 2018

\begin{abstract}
Drawing on a comparison of two different nature reserves (NRs) in China, this paper explores the effect of the establishment of the NRs and the associated tourism industry development on local livelihoods, and analyzes why they differed. One hundred semi-structured interviews were administered with local elites, villagers, and government officials to identify livelihood changes. Based on a modified sustainable livelihoods framework, we found that the livelihoods of people living in both NRs had improved, but there was a loss of traditional culture and weakened social connections. The provision of alternative livelihoods options was critical for local people, with these options needing to have strong connections to China's development policies. The results point to the importance of providing alternative livelihood strategies when establishing new conservation areas. This requires holistic management plans that not only address conservation, but also consider the impacts on local people.
\end{abstract}

Keywords: conservation; tourism industry; local people; protected area; sustainable livelihoods

\section{Introduction}

There were no national protected areas (PAs) in China until 1956, when the Dinghushan nature reserve was established in Guangdong Province. With the opening up of China to the West, the first Western-funded project- the World Wildlife Fund (WWF) panda conservation project-started in China in 1979 [1]. As with many other developing countries, China's nature reserves (NRs) have been greatly influenced by Western countries, and attracting international funding is one of the reasons for designating sensitive areas as nature reserves [1,2]. There are many types of PAs in China, including forest parks, scenic resorts, NRs, wetland reserves, geoparks, and others. In all of these, NRs usually focus on the conservation of terrestrial biodiversity, and around $80 \%$ of NRs are forested. Since the 1980s, when there were 19 NRs, China's NR network has grown substantially, and by the end of 2016, 2740 NRs had been established [3].

In most instances, NRs in China have been established in places already occupied by local people. There are about 30 to 60 million people living in or around NRs; many of them are impoverished rural villagers relying on products from natural ecosystems to sustain their livelihoods $[4,5]$. Due to this, most NRs have three zones: a core zone, where human activities are strictly prohibited; an experimental zone, where local people still live, and where some human activities are allowed, including scientific experiments, teaching, visiting, tourism, the reproduction of rare and endangered wildlife, farming, and other activities that create a living for local people; and a buffer zone that lies between the core and experimental zone, where human activities are mostly forbidden, with the 
exception of scientific research and monitoring [6]. As with many other countries, the development of tourism has been seen as an opportunity to solve the contradictions between conservation and the maintenance of local people's livelihoods [7]. Since the 1990s, NR tourism has developed rapidly, and now involves $80 \%$ of Chinese NRs [8]. Nature-based tourism has the potential to contribute both socioeconomic and environmental benefits, such as reducing poverty, creating more jobs to reduce the reliance on natural resources, improving health and education, and empowering local people [9-12]. However, many researchers have concerns about advocating nature-based tourism as a panacea for reserve-based communities because of some issues associated with it, including internal and external collaboration, effective leadership, and socioeconomic benefits [13-16]. In addition, many negative effects have been reported, including flagship species being adversely affected, the population declines of sensitive species, habitat alteration, pollution, conflicts with local communities, the exclusion of the local community, and insufficient revenue creation for conservation [9].

In order to improve how people adapt to NRs and their outcomes in China, it is important to understand how people perceive the ways in which the establishment of NRs and subsequent tourism development impact their livelihoods. This paper presents results from two national NRs: Jiuzhaigou and Shennongjia in China, with the analysis based on a sustainable livelihoods framework.

\section{Capital Theory and the Sustainable Livelihood Framework}

Many approaches to the measurement of welfare or livelihoods have been developed. Most approaches employ composite indicators to represent the welfare statement. These methods usually aggregate information into a single (usually monetary) indicator, such as gross domestic product (GDP), but have been criticized for their heavy reliance on monetary value, and because they ignore other aspects of livelihoods [17]. As a result, many other approaches have been created that adjust GDP or other macro-economic aggregates by adding social capital, natural capital, human capital, or government efficiency. For example, the Genuine Savings indicator used by the World Bank adds education (human capital) and the value of natural resource depletion $[17,18]$. Most of these synthetic approaches are based on three dimensions: social, environmental, and economic, which are consistent with the Brundtland Commission's definition of sustainable development [19].

More recently the 'capital approach' has been used for sustainable development theory and as a framework for further analysis [20-22]. 'Capital' is a traditional concept in economics, but has been broadened to include human capital, social capital [23], and natural capital [17]. The five capital theory states that livelihoods and welfare depend on service flows from five different assets (natural, social, human, physical, and financial capitals, see Table 1) [22].

Table 1. Definition of the capital assets (adapted from the DFID) [24].

\begin{tabular}{cl}
\hline Natural Capital & $\begin{array}{l}\text { The Basic Natural Resources Used to Generate the Products and } \\
\text { Services that Create Livelihoods for Local People }\end{array}$ \\
\hline Physical capital & $\begin{array}{l}\text { The material products, including infrastructure and goods, that are } \\
\text { used to support livelihoods (e.g., shelter and buildings; tools and } \\
\text { equipment used to maintain land-based livelihoods; infrastructure } \\
\text { related to transport, communication, and energy production) }\end{array}$ \\
\hline Human capital & $\begin{array}{l}\text { The health, as well as the skills and knowledge, needed by people to } \\
\text { achieve their objectives, including maintaining their livelihoods }\end{array}$ \\
\hline Financial capital & $\begin{array}{l}\text { The financial infrastructure needed by people to maintain their } \\
\text { livelihoods. This includes access to credit, various different types of } \\
\text { savings, and the ability to make and receive payments }\end{array}$ \\
\hline Social capital & $\begin{array}{l}\text { The inter-relationships amongst people that enable them to maintain } \\
\text { their livelihoods. This also includes the rules, norms, and sanctions } \\
\text { that may be associated with particular institutions }\end{array}$ \\
\hline
\end{tabular}


Support for the use of capital theory to measure sustainability is mounting in the scientific literature [17,24-27]. Kulig et al. [22] indicated that the lack of uniformity in welfare debates in the past 40 years is due to the lack of a proper theoretical basis: the capital approach provides a consistent and theoretically sound measurement method.

The Institute of Development Studies team defined a 'sustainable livelihood' as one that "can cope with a recovery from stresses and shocks, maintain or enhance its capabilities and assets, while not undermining the natural resources base" [28]. This definition emphasizes the maintenance and improvement of assets while not diminishing natural resources. The Department for International Development (United Kingdom) (DFID) developed the sustainable livelihoods (SL) framework [24], based on the five-capital theory. It focuses on human well-being and sustainability rather than economic growth $[24,28]$. The SL framework addresses the five main assets that affect people's livelihoods [24]. Instead of working in a linear manner, the SL framework focuses on people and how to help different stakeholders structure the many factors affecting their livelihoods, their relative importance, and the way in which they interact [24]. The SL framework has quickly become a widely used tool for analyzing the social impacts of conservation. The livelihoods of local people can be adversely affected by the establishment of NRs and the limitations imposed upon their use of natural resources. In such circumstances, local people may seek alternative livelihoods strategies, such as tourism development. Such changes can have an impact on the sustainability of the livelihoods of local people, as all five capitals will change accordingly.

The sustainable livelihood literature provides a frame of reference for this study. Using it as a theoretical framework, we examine how local people in NRs in China have secured their livelihoods during the establishment of NRs and the subsequent development of tourism. Our objective was to better understand how their livelihoods changed and how these changes were mitigated.

The framework for this study is shown below (Figure 1).

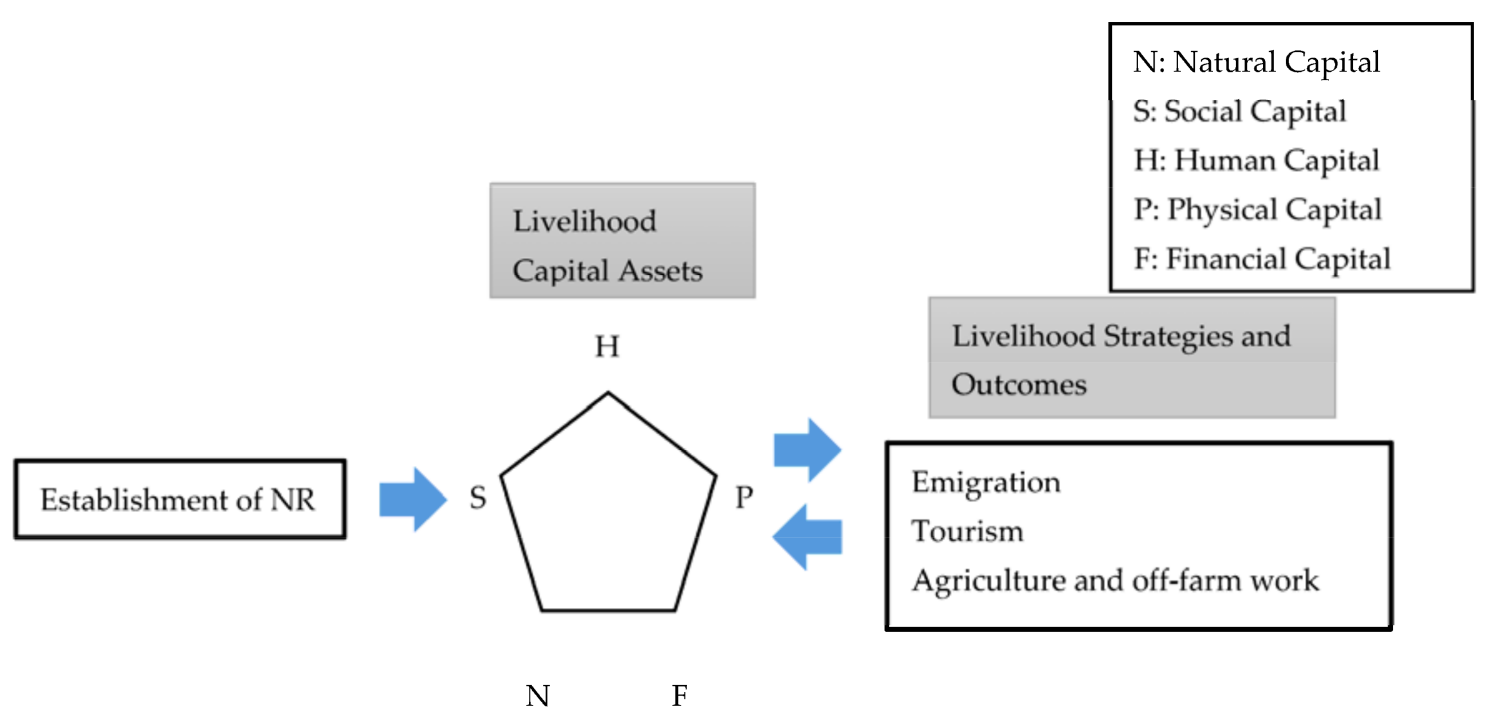

Figure 1. Livelihoods Capitals, Strategies and Outcomes Framework (Modified from Sustainable Livelihoods Framework [24,28]).

\section{Study Sites and Methods}

\subsection{Area of Study}

Two NRs were chosen for this study: Shennongjia National Nature Reserve (SNNR) in Hubei Province (central China) and Jiuzhaigou Biosphere Reserve (JBR) in Sichuan Province (western China) (Figure 2). This selection was based on a pilot study conducted in September 2015 when five NRs were visited: Jiuzhaigou, Baihe, Shennongjia, Dajiuhu, and Wuyishan. Interviews and informal discussions 
with local people and officers were completed at each. Based on the information gained, two areas with well-developed tourism were chosen for further investigation. Basic information about SNNR and JBR is provided in Table 2.

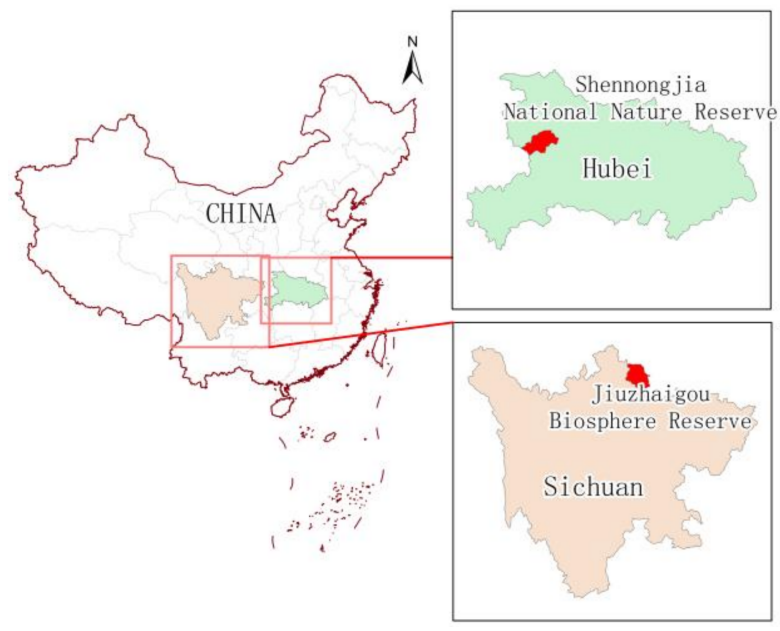

Figure 2. Locations of the Study Areas.

Table 2. Comparison of study areas. SNNR: Shennongjia National Nature Reserve; JBR: Jiuzhaigou Biosphere Reserve.

\begin{tabular}{ccc}
\hline & SNNR & JBR \\
\hline Location/Province & Central/Hubei & West/Sichuan \\
Establishment date & $110^{\circ} 3^{\prime}-110^{\circ} 33^{\prime} \mathrm{E}, 31^{\circ} 21^{\prime}-31^{\circ} 30^{\prime} \mathrm{N}$ & $103^{\circ} 46^{\prime}-104^{\circ} 50^{\prime} \mathrm{E}, 32^{\circ} 55^{\prime}-33^{\circ} 20^{\prime} \mathrm{N}$ \\
Average rainfall & 1982 & 1982 \\
Size & $1440 \mathrm{~mm}$ & $600 \mathrm{~mm}$ \\
Landscape & $705 \mathrm{~km}^{2}$ & $730 \mathrm{~km}^{2}$ \\
Altitude & Mountainous & Mountainous; 114 lakes \\
Income ${ }^{1}(2013)$ & Average altitude $1584 \mathrm{~m}$ & Average altitude $2930 \mathrm{~m}$ \\
Population & 6305 yuan ${ }^{2}(927$ US dollar) & 25,000 yuan $(8928$ US dollar $)$ \\
Main nationality & 8370 & 1403 \\
\hline
\end{tabular}

${ }^{1}$ This income is the average income per person per year within the SNNR and JBR areas; ${ }^{2}$ The average exchange rate in June 2017 between the United States (U.S.) dollar and Chinese Yuan is: 1 USD = 6.8 RMB.

\subsection{Jiuzhaigou Biosphere Reserve}

JBR is in the far north of Sichuan Province. It is a national NR, a designated scenic spot, and a World Heritage Site. It is renowned not only for its diverse forest ecosystems and narrow conic karst landforms, but also for its rich biodiversity and culture [29]. 'Jiuzhaigou' means 'a valley of nine villages', but now, following village amalgamation, only four are left. Tibetan communities have inhabited Jiuzhaigou for at least 500 years, following a traditional farming and herding lifestyle that was isolated from mainstream Chinese politics until 1974, when state foresters reported the importance of protecting and conserving the area from logging to the provincial government [10]. The geology of JBR is comprised of 114 calcareous lakes surrounded by forested mountains [30]. A number of endangered plants and animals, including the giant panda, golden monkey, Sichuan takin, and more than 150 species of birds inhabit the valley [31]. The total area of the reserve is $730 \mathrm{~km}^{2}$, of which only $50 \mathrm{~km}^{2}$ of scenic area is open to the public [10].

Tourism in JBR started in 1984, two years after JBR was established. Since then, the traditional self-sufficient lifestyle, based on slash-and-burn cultivation, grazing, logging, and hunting, has given way to tourism-related activities such as running home-style accommodation and restaurants, 
providing information to visitors, and other tourism-related services. With this change, the annual per person income has risen from 23 US dollars in 1978 [30] to about 3700 US dollars in 2013. Since 1997, the number of visits to JBR has increased very rapidly, especially following the completion of a highway from Chengdu (the capital of Sichuan Province) to JBR. Prior to highway construction, there were fewer than 170,000 annual visits to JBR; however, in 1998, the visitor numbers doubled to 340,000 [10]. Over the last two decades, visits have increased 20-fold, with over five million tourists visiting JBR in 2016. The revenue from tourism has reportedly been reinvested in park infrastructure construction, conservation, and monitoring activities.

The high number of visitors has led to concerns about the sustainability of JBR. In order to reduce environmental stress, a green bus system for ferrying tourists started in 1999, and a daily limit of 40,000 (Data provided by JMA) visitors was implemented. In 2003, all of the home-based restaurants and accommodation in the park were closed [32]. However, even with such initiatives in place, there are still concerns for the environmental well-being of JBR.

JBR is also prone to geological disasters, especially landslides and debris flows. To mitigate these hazards, the Jiuzhaigou Management Administration (JMA) initiated debris flow control projects in 13 ravines from the 1980s onwards. In 2008, an 8.0 Ms (Ms: Surface wave magnitude) earthquake occurred in Wenchuan County, Sichuan Province, about $300 \mathrm{~km}$ away from JBR. This earthquake caused significant disruption to transportation routes in much of the northern Sichuan province and completely cut off JBR for some time [32].

\subsection{Shennongjia National Nature Reserve}

SNNR is located in the northwest of Hubei Province, Central China. It was established as a provincial nature reserve in 1982, and four years later, it was gazetted as a national nature reserve. As a result of crustal movements and erosion over the years, the topography in SNNR features an unusual pattern of mountains and rivers, with the forest cover exceeding 90\% [31]. The conservation of SNNR is not only important for biodiversity, but also important for the safety of the Yangtze River, especially in relation to soil and water conservation [33].

The total area of SNNR is $705 \mathrm{~km}^{2}$, of which $52 \%$ is considered as a strictly protected area, and $34 \%$ is designated for sustainable land-use activities, including tourism. As with JBR, the number of visitors has risen rapidly. In 2005, there were 125,000 tourists, while in 2010, visits had doubled to 236,000 [34]. In 2013, the tourism industry accounted for 50.3\% of GDP in the Shennongjia region, but difficult transportation conditions and limitations on the use of natural resources have resulted in farmers in the reserve being poorer than those living outside. In 2013, the average annual income per person for rural households in Shennongjia was only 751 US dollars (5110 Chinese Yuan) [35]. Farmers' livelihoods varied widely between villages due a range of factors, including the natural resources, transportation, and availability of information [33].

\subsection{Research Methods}

This research aimed at understanding the changes affecting local people's livelihoods in nature reserves, as perceived by them. A qualitative research approach was used to understand perceptions of the impacts of the NR and the ensuing tourism development on local people's livelihoods. Qualitative methods are frequently used in community research [36]. Data were collected through face-to-face semi-structured interviews with key village informants, village residents, and government officials, through observation, as well as by consulting related documents.

Face-to-face semi-structured interviews were used as the primary method to elicit information about people's experiences of changes in their social and economic situations, livelihood management practices, local governance structures, benefit-sharing mechanisms, challenges that they faced after the PA was established, and benefits from tourism activities. Fieldwork was conducted from August to November 2016. The selection of interviewees followed two principles: the first involved identifying local influencers, key leaders, and important village residents (the importance principle). The second 
aimed to ensure that different gender, socioeconomic status, and ethnicity were included (the variety principle). In total, 100 interviews were conducted ( 50 from JBR, and 50 from SNNR) (see Table 3 for details). With the permission of the participants, most of the interviews were recorded. When this was not possible, comprehensive notes were taken. Documents were also collected for this study, including internal government reports in Shennongjia, Regional Annual Economic Reports for Shennongjia and Jiuzhaigou, the Jiuzhaigou Scenic Area Plan (Revised version 2005), Jiuzhaigou County Annals, Jiuzhaigou Local History, an autobiography of the first JMA director (Book: Forever Jiuzhaigou), news items from the office website of JBR (https:/ / www.jiuzhai.com/), and related news from the Internet, newspapers, and other public texts. Documents were used as supplementary materials for the analysis, enabling triangulation of the material collected in interviews.

Table 3. Number of participants by type and gender in each nature reserve.

\begin{tabular}{ccccccc}
\hline & \multicolumn{3}{c}{ Type } & \multicolumn{2}{c}{ Gender } \\
\cline { 2 - 7 } & $\begin{array}{c}\text { Management } \\
\text { Administrative } \\
\text { Officers }\end{array}$ & Local Elites & $\begin{array}{c}\text { Administrative } \\
\text { Village } \\
\text { Leaders }\end{array}$ & Villagers & Male & Female \\
JBR & 9 & 9 & 6 & 26 & 31 & 19 \\
SNNR & 3 & 2 & 3 & 42 & 29 & 21 \\
\hline
\end{tabular}

A directed approach analysis was used for the content analysis. Both deductive and inductive approaches were employed. The analysis started by identifying key concepts as initial categories. Initial categories included: social capital, financial capital, physical capital, human capital, natural capital, emigration, tourism activities, agriculture, and off-farm work. An inductive approach was used to identify new codes and refine the a priori ones. NVivo 11, a qualitative data analysis software package, was used to help manage and code the data. The transcriptions of the interviews were checked by some of the participants as a means of ensuring data accuracy and validity. A final report of this study was also sent to participants.

For this study, selecting communities as cases means that the results were based on these two NRs in China. It is not possible to generalize about the whole population, but the information can help gain an in-depth understanding of the issues raised by the research questions. To justify this limitation, interviewees were selected based on the variety principle, providing different viewpoints that have strengthened the findings of this study. Other strategies, including observation and the review of documents, were used for triangulation.

\section{Changes in the Five Capitals}

\subsection{Natural Capital}

The interviews revealed that all five categories of capital were affected by both the creation of the NR and the subsequent development of tourism in both JBR and SNNR. For natural capital, the economic activities of the local people before the creation of the NRs were focused on self-sufficiency through slash-and-burn agriculture and hunting, and all of their activities heavily relied on natural resources. Due to the low population density in both NRs and their rich natural resources, the per person occupancy of the volume of the natural resources was high. One interviewee in JBR (Interview JBR No. 13) commented:

"During the three years of the Great Chinese Famine (between the years 1959 and 1961), we heard that some people starved to death in other villages, but this never happened in our village ... Our land is fertile... We could hunt in the forests ... and we have a lot of fish in the lakes. We Tibetans do not eat fish (for religious reasons), but when the famine happened, we could eat fish a little bit ..." 
The situation with natural resources in SNNR is similar to JBR. Local residents who lived within the NR boundaries indicated they had far more than enough food provided by nature. One interviewee (interview SNNR No. 4) commented:

"In the mountains, our land was fertile, and we could harvest lots of food each year, far more than we needed ... It was better than outside (outside of the mountain area) ... but there was no electricity or road."

Compared to other places, they were experiencing good lives, especially during the period of the planned economy (which lasted from 1950 to the end of the 1970s), when many rural villagers elsewhere suffered badly.

The creation of NRs in JBR and SNNR limited the use of natural resources. The park regulations forbade hunting, grazing, and logging, but the managers in both places did not enforce the regulation for small-scale logging for firewood or grazing. However, there were some restrictions on logging and grazing. For example, logging for firewood was not allowed in natural forest, local people were encouraged to cut branches rather than taking the whole tree, small-scale grazing was allowed, but not in immature forests, and the collection of herbal medicines was allowed provided that there was no damage to the forest.

The limitations on the use of natural resources had a bigger effect on the residents of SNNR. Immediately after the establishment of the NR, JBR started tourism development and greatly reduced the reliance of local residents on natural resources. In SNNR, local people had much less chance to participate in tourism-related jobs. One interviewee (interview SNNR No. 20) commented:

"PA establishment had great effects on us ... all (natural resources) are protected and we are not allowed to touch them."

In addition, the national Return Farmland to Forests Project (RFFP) started in 1998, and greatly affected both locations. Every household living in the JBR area converted all of their croplands to tree plantations; in SNNR, most of the households converted only part of their croplands. The RFFP further reduced peoples' reliance on natural resources in JBR.

Local people in SNNR raised complaints about the establishment of the NR. In addition to being limited in their use of natural resources, many people mentioned that wild animals frequently destroyed their croplands, but they received no compensation. Before the NR was established, local people used firecrackers or guns to scare away wild animals, but this was forbidden after establishment, and all of the hunting guns were confiscated. As a result of environmental protection regulations, wild animal numbers increased, and damage to cropland by wild pigs and monkeys increased.

Although the creation of the NRs limited the direct use of natural resources by local people, biodiversity conservation measures also created benefits, including fewer natural disasters, clean water, and opportunities for recreation. People in JBR had a very high awareness of environmental protection, as respect for nature is part of their Tibetan religion. In addition, they recognized that a healthy environment and beautiful scenery could attract tourists.

\subsection{Physical Capital}

Physical capital was enhanced by the creation of the NRs and the development of tourism, especially the infrastructure, including transportation, communications, electricity networks, renovated houses, TV broadcasting services, garbage disposal services, and energy supply. In JBR, the improvement in infrastructure was a direct result of tourism development. For example, demand for tourism in JBR accelerated the construction of transportation corridors. Hydropower was implemented in JBR specifically to protect the environment and encourage sustainable tourism. One officer interviewed in JBR (interview JBR No. 45) commented:

"In order to reduce logging in JBR, three small hydropower stations were built by JMA. You (local people) need electricity, but I need to protect environment ... We made a trade." 
The enhancements to the infrastructure not only addressed the needs of tourists but also benefited residents. As with JBR, the enhancement in physical capital in SNNR was partly the result of tourism developments. A large proportion of the enhancement occurred as a result of development projects conducted by the county and nationally, especially through the Cuncun Tong Project ("Cuncun Tong" means connecting every village, in place since 1998"). This project enabled great progress in rural areas, particularly in poverty-stricken areas lacking access to appropriate rural infrastructure. However, not every village in SNNR received infrastructure improvements. Some villages remained inaccessible, resulting in residents migrating to other areas. Most people in JBR had vehicles, but in SNNR, most people used motorcycles, as they were cheaper.

Many residents in JBR purchased houses in big cities, such as Chengdu, the capital of Sichuan Province. They usually choose to live in Chengdu during the winter, which is also the off-season for tourism.

In contrast, people in SNNR bought or built new houses in town or moved from hilltops to valley bottoms to be near the road (as there is no road access to the top of hills), as they cannot afford the housing price in cities. For many, the primary motivations to move have been convenient transportation, proximity to schools and services for their children, and access to job information.

\subsection{Financial Capital}

The creation of the NR has reduced the financial capital of both JBR and SNNR. Before the establishment of the reserves, cash income for people in both places came from selling non-timber forest products (NTFPs), wild animal meat, wood, and charcoal. Since the establishment of the NRs, local people have lost these sources of income. However, the China Economic Reform policy has led to huge labor demands and provided off-farm work opportunities. In 2014, the salary income (off-farm income) per person in SNNR was 3228 yuan (474 US dollar), while the agriculture-related income was 2480 yuan (364 US dollar). Off-farm work brought in more income to local households. Tourism development did not bring many direct benefits to the people in SNNR, as most were not living near the tourism center, and some were far from the main road. Labor opportunities related to tourism developments, such as construction work, restaurant and hotel staff, and drivers, have increased. One interviewee (Interview SNNR No. 10) in SNNR stated:

"There are many construction jobs here, and I work as a mason. I could earn 120 yuan (17 US dollar) to 150 yuan (22 US dollar) per day. But those jobs are not continuous; sometimes I can find a job, sometimes not."

In JBR, local people received a share of the tourism entrance fees to the reserve. Each year, $7 \%$ of the entrance fees were distributed equally to local people. Twenty percent of the JBR administration employees are local people, resulting in steady salaries. Local people can also get income from tourism-related services such as photography, renting traditional clothes, and selling souvenirs. Most of the local people own stocks in the Nuorilang Restaurant (the only restaurant within JBR).

In both JBR and SNNR, financial services organizations have been established that can provide saving and credit services. However, most people indicated that if they needed a loan, they would rather borrow money from relatives or friends due to the complex processes involved in formal loans and their lack of collateral. One interviewee (interview JBR No. 6) commented:

"We prefer to borrow money from friends and relatives, very few cases to get loan from the bank... unless there is no other solution, we may consider the bank... It needs mortgage and other processes, which is not convenient for us."

\subsection{Human Capital}

In both JBR and SNNR, the current generation (35-50 years old) and older generation (older than 50 years old) are very poorly educated due to the past low level of economic development and infrastructure. One interviewee (Interview SNNR No. 31) mentioned: 
"One reason why I quit school after third year was because the elementary school in our village only had first to third year... we would have to go to another school in another village for the fourth year and above. The road was very dangerous, especially when it rained heavily; children could be washed away and this happened every year."

Education has improved for younger generations in both JBR and SNNR, although there are differences between the two NRs. In JBR, due to the fast economic growth resulting from tourism, local residents are now living better lives and have indicated strong willingness to support a better education for their children. During this study, in all four villages in JBR, nobody registered their children at the elementary school in the local town, claiming that its education quality was poor. They preferred to send their children to private schools or public schools in big cities such as Chengdu and Mianyang. As they are not selecting the local schools, which provide local people with free education for nine years, they have to pay a high "school selection fee", and most of them have to pay dormitory fees. As a result, most young (under 35) people in JBR have the opportunity to receive a better education, and some have opportunities to study abroad. In SNNR, the situation is less positive, and most interviewees indicated that the education level within SNNR is lower than elsewhere in Hubei Province. However, they could not afford to send their children to schools outside SNNR.

People in both JBR and SNNR agree that medical conditions have improved significantly over recent years. One interviewee (interview SNNR No. 34) recalled her own experience:

"When I was a kid, there were no health services nearby, and it took hours to get to the closest clinic. Most of the time, if I got a fever, my parents would ask me to drink some water mixed with charcoal ash. I didn't understand why, but that was what people did in our village."

Health services were extremely limited in both JBR and SNNR in the past. Nowadays, almost all of the people in both places have joined the New Village Cooperative Health Insurance, an initiative led by the Ministry of Health of the State Council established in 2003 to overhaul the healthcare system. It is particularly intended to make healthcare more affordable for the rural poor. However, this improvement was unrelated to the establishment of the NRs or tourism development. In JBR, people preferred to get healthcare services in big cities, as they thought that local health services were inadequate, and they could afford to go outside the village. In SNNR, most of the residents chose to receive healthcare services locally as they could not afford the better healthcare services offered in large cities.

In JBR, local residents have been able to utilize tourism-related practices to improve or develop new capabilities. For example, their language skills (Mandarin Chinese in addition to the Tibetan language) have been improved, especially amongst the old generation. Their marketing skills (running restaurants and hotels) and tourism service skills (photography and acting as tour guides) have also improved. The number of successful entrepreneurs has gradually been growing in the area. In contrast, most people in SNNR have not had such opportunities and have continue to work on farms or as laborers.

\subsection{Social Capital}

The interviews revealed that the establishment of the NRs had little effect on the social capital of local communities, but the ensuing tourism development did.

During the 1990s, in order to minimize the competition amongst villagers to attract tourists and provide better services, a joint company was founded in JBR by local villagers to provide service standards and equitable revenue sharing. Members of the board of directors were selected by the villagers. This joint venture not only brought a steady revenue from tourism, it also organized and united the local community in a new way. However, following a rise in environmental concerns, all of the business operations were prohibited within JBR, and the joint venture was closed down in 2003.

Despite this setback, social capital in the local communities has remained strong, and most of the villagers attend social and/or religious events. There are many religious events in JBR each year, 
with villagers attending these for good luck. The strong Tibetan Buddhism ideology undoubtedly strengthens social ties in JBR. During the fieldwork for this study, a couple were married, and more than 800 people (more than half of the population) attended the ceremony, something that they claimed was very normal. The new couple prepared free meals for all of the villagers for a period of two days. They set up a temporary tent, and almost all of the women in the village came to help with the cooking, while the men helped with other wedding preparations. In JBR, due to the isolation of the villages in the past, most local people married within the same village; as a result, most villagers are related to each other. These marital connections have contributed to the strong social relationships amongst the villagers. For example, when local people need financial help, they usually ask relatives or friends in their village, preferring not to seek funds from banks. As most young children now go to school outside JBR, the strong connections with their family and community are being lost. Many can no longer communicate in the Tibetan language. In addition, some interviewees expressed their concerns about the effects of the market economy on their community, with an increasing gap between the rich and poor and a loss of traditional social values.

Strong social connections also exist in SNNR. Local people used to help each other during the busy farming season. Similar to JBR, the isolation of the villages in the past led to many people getting married within the community. As a result, most people in each community are relatives, and in some villages, many villagers have the same family name. Social connections have played an important role in sharing information about the outside world. One interviewee (Interview SNNR No. 46) mentioned:

"We moved out from the mountains in 1992, through the help of relatives. We had poor living conditions in the mountains, it got harder and harder for men to get married, as local women preferred to marry outsiders. After a woman got married and moved out, some of her relatives, such as cousins, brothers, and sisters would move out under her help."

Today, off-farm work has become the primary source of income for most households in SNNR. People in the same community share job information and communicate frequently. Even people who moved from the mountain tops prefer to live near or in the same community. Many of them have borrowed money from their relatives to build or decorate new houses on the valley floors or near the town.

\section{Livelihood Strategies and Outcomes}

Many different livelihood strategies have been employed in the NRs, including migration, wage employment, agriculture products, and tourism enterprises.

\subsection{Emigration}

Those interviewed indicated that emigration took place in both JBR and SNNR, but in different ways.

In JBR, there were two stages of migration. The first occurred in the 1990s, when villagers who lived in remote villages voluntarily moved closer to the main road in order to develop tourism. This move brought obvious benefits, as it was much more convenient for them to run family inns and restaurants and attract more tourists. Further changes occurred after 2000, when more and more residents bought houses in big cities (e.g., Chengdu). Some of the villagers started moving temporarily to cities during the winter season, and some chose to live there most of the time.

In SNNR, there were four different types of emigration. The first was related to marriage. Some females married people outside their village, using this as a way to leave their home villages. They would then help some of their relatives to move out. The second type was forced emigration. This occurred around 2003, and involved people who lived within the biodiversity core area of the NR. People were forced to move out with very little compensation, and they had to find new homes by themselves. This practice was abruptly terminated. The third type was voluntary emigration without help from others. Only households with relatively good economic conditions could choose to move out this way, as they needed to have sufficient financial capital to support them while they started new 
lives elsewhere. Nowadays, many people choose this way because of concerns over the needs of their children's education and because of easy access to laboring jobs. One interviewee (Interview SNNR No. 20) who migrated from the hills three years ago commented:

"Living here (at the foot of the hills) is much more convenient than before. In the past, we had to carry everything home, even buying a bag of salt takes hours... It takes too long for children to go to school, and we were worried about our children's safety, especially on bad weather days ... In the past, it was also inconvenient for me to find laboring jobs. If someone called and asked me to work immediately, I could not, as it took me hours to go downhill. But now, if I get a phone call, I could arrive there soon."

The fourth type is emigration associated with the central government's Target Poverty Alleviation Policy (in Chinese: Jing Zhun Fu Pin). The SNNR government built houses in the valley bottoms and moved poor people from the hilltops so that they could start new lives. This policy targeted the very poor individuals in SNNR.

\subsection{Tourism as a Livelihood Strategy}

Tourism acts as an important livelihood strategy in both places, especially in JBR, where most families left farm work to work in tourism. Activities related to tourism in JBR and SNNR are shown in Table 4. Tourism provides employment and other opportunities for both places, although people in JBR are more involved than those from SNNR. This is because communities in JBR are geographically closer to the tourism heartland, and they were able to be involved in tourism investment at an early stage of tourism development. In 1984, the first hotel in JBR provided a tourism service: a homestay. The first homestay was built by a local villager; then, more villagers followed suit. However, these homestays, which brought local people considerable income, were closed in 2003 because of concerns about environmental pollution. Although some compensation was provided by distributing a portion of the entrance fees to villagers, there was considerable dissatisfaction with this action.

Table 4. Sources of tourism income.

\begin{tabular}{l}
\hline Direct Income from Tourism for the Local Community: \\
\hline JBR \\
\hline
\end{tabular}

- Administration employment in the park $(20 \%$ of the administrative staff are local people, employed as rangers, managers, and maintenance staff), for both formal employment and temporary employment during peak seasons

- Semi-community-run Nuorilang restaurant: community has $49 \%$ of the equity

- $\quad$ Entrance fee redistribution $(7 \%$ entrance fee shared with local people)

- Sales of souvenirs

- Individually-run enterprises: restaurants and hotels

- Leasing land for parking lots

- Sales of local products (e.g., honey, chestnuts, wild kiwi fruits)

- $\quad$ Temporary laboring jobs for NR-related construction (hired by SNNR administration)

- Income from homestays (very few)

Indirect Income from Tourism for Local Community:

JBR

SNNR

- Wages employment from hotels, family inns, and restaurants
- Wages from employment from hotels, family inns, and restaurants

- Wages from employment in labor jobs (e.g., construction) 
Prior to 2000, most of the tourism services in JBR, such as restaurants, hotels, guides, and photo services, were provided by local communities, with a joint company being created by the local people to manage these services. In contrast, tourism development in SNNR was led by a government-owned company called "Shen Lv", and local villagers living within the NR were mostly excluded from the development process.

\subsection{Agriculture and Off-Farm Work}

Agriculture was abandoned in JBR in 2000, but agriculture-based products still comprised 35\% of the households' net income in SNNR in 2014. However, some agricultural products are for consumption, and are not for sale. Therefore, Agriculture contributes to local livelihoods much more than is apparent from net income, as it is significant for local food security. Major agricultural crops include maize, potatoes, soybeans; stockbreeding includes pigs, cattle, goats, and chickens. The destruction of crops by wild animals near or within SNNR has been an important problem. Many local residents in SNNR have had to build a shelter near their farmland to protect their crops during the night. As a result, many local people think that the conservation of biodiversity could negatively impact their benefits. NTFPs from the forest include honey, wild fruits (such as wild kiwi fruits), and nuts (such as chestnuts). Some villagers have chosen to collect these NTFPs and sell them to tourists.

Along with tourism, off-farm work plays a very important role in improving livelihoods in both NRs, especially in SNNR, where off-farm work now exceeds agriculture as a source of income. The China Economic Reform started in 1978, almost at the same time as the establishment of SNNR. This reform marked an economic change from a planned to a market-based economy. Subsequently, there was a high demand for labor arising from industrial development in the area. This introduced rural people to new opportunities and a new livelihoods strategy. Economic Reform proposed off-farm work as an alternative, and this contributed to the reduction in reliance on natural resources, and alleviated the opposition to the NRs.

\subsection{Linking Different Capitals for a Sustainable Livelihood}

In both JBR and SNNR, the different capitals changed over time, and most capitals have improved since the establishment of NRs. In order to pursue the sustainability of the livelihoods, it is important to see whether local people could maintain or enhance these capital assets. In both places, local people reduced their reliance on natural resources; meanwhile, significant growth in human, financial and physical capital have been detected. However, a decline in social capital in JBR has been observed amongst the young generation, as most of them left their village for school when they were young.

\section{Discussion}

The two studies indicate that the impacts of the NRs on local livelihood strategies and outcomes have been mixed.

Traditional livelihood strategies such as logging, hunting, and agriculture are usually heavily reliant on natural resources, and are usually seen to be negatively affected by NRs. NRs are viewed worldwide as a substantial constraint for local people to secure their livelihoods [37], and conflicts are often at the heart of NR creation and maintenance [38]. This is because NRs place limits on people's livelihood choices, while sometimes failing to provide alternatives. In JBR, local people abandoned their old lifestyle — a traditional lifestyle based on agriculture — and chose a new livelihoods strategy: tourism. People in JBR are very environmentally-conscious, as they know that a healthy environment is the foundation for successful tourism development. Thus, they have the same interests as the government in regard to protecting and conserving the environment. Conversely, in SNNR, local people still rely heavily on natural resources, as tourism in this area has not reached the same successful level of JBR, and has not yet provided sufficient alternatives to improve their livelihoods. The first priority for people in SNNR is to enhance their livelihoods, but the priority of the administration is to 
conserve biodiversity. This divergence in priorities has caused major conflicts between the local people and the government responsible for the establishment of the NR.

Developing tourism in PAs has the potential to improve livelihoods significantly for local communities, but many people in SNNR lack opportunities to participate for two reasons: the top-down approach excluded local people from the design, planning, and management stages of tourism development in the area, and local people lack the necessary preconditions, including geographic advantage, initial funds, and management knowledge. Tourism development could introduce new sources of income and alternative livelihood opportunities, as demonstrated at JBR and many other places in the world [39]. An increase in financial capital could positively affect other capitals by improving human capital through education and health services, and improving physical capital, as indicated by vehicle purchases, house renovations, and new house purchases. Nonetheless, tourism development and market economics have led to the loss of traditional knowledge, language, culture, and even social connections [11]. This is obvious in JBR, where younger generations have left their homes to go to schools in big cities, leaving behind their local social networks.

Local people in SNNR have different interests to the local administrative department. NRs have the potential to protect biodiversity while improving local people's livelihoods, but only when local people are considered and help find alternative livelihood options. In such cases, work opportunities are still crucial as alternative livelihood strategies for current and younger generations, as they contribute to the accumulation of financial capital, which plays an important role in improving other related capitals and pursuing a better livelihood.

The five livelihood capitals are closely linked to each other, which calls for an interrelated method to improve livelihood capabilities [40,41]. Income streams are important to villagers, but the evidence suggests that other capitals are equally meaningful for local people. For example, social capital is important for both the NRs studied here: in JBR, local people could not start the joint operation to run the tourism business without having strong social capital; in SNNR, social capital plays an important role in information sharing and emigration. In addition, without physical capital improvement, JBR could not develop homestays and could not connect with the outside world. Policy support in improving capital assets, especially physical capital, needs to be emphasized, as it is significant in local people's livelihoods. Physical capital improvement is highly related to infrastructure construction investments made by the government, and there have been many efforts to enhance transportation, communication, and other infrastructure in rural areas. These have generated positive impacts on rural people's livelihoods, especially for the poor. However, most of these policies are quite separate from conservation-related policies. Local livelihoods are often not even mentioned in conservation policies due to the lack of financial support, thus making it a 'paper policy'.

Compared to involuntary emigration for conservation, voluntary emigration is preferred by the government for two reasons. It reduces criticism and unrest over involuntary resettlement and voluntary resettlement is cheaper, as there are no livelihood restoration requirements or compensation requirements (international standards for resettlement are only applied to involuntary resettlements) [42]. Voluntary emigration as a livelihoods strategy could be effective, as emigration can lead to a rapid growth in some capital assets. In SNNR, voluntary emigration immensely improved the physical capital—transportation—for local villagers. However, as discussed by Schmidt-Soltau and Brockington [42], it is hard to distinguish between a real or forced choice when it comes to voluntary emigration. It is also questionable whether voluntary resettlement can really bring more choices to the affected people. The options for affected people are either to stay-a choice that includes little or no compensation, restricted access to natural resources, few or no opportunities to benefit from resources, and coping with the crop damage caused by animals—or they can decide to move away [42]. In the case of SNNR, 'voluntary emigration' is driven by both push and pull factors. On one side, inconvenient living conditions 'push' people to move. It is more about 'have to' than 'want to'. On the other side, large-scale urbanization and increased job opportunities in cities attract many people, 
especially within the ambitious young generation. In this process, the government should consider people's livelihoods by providing support for voluntary emigration.

\section{Conclusions}

In this study, qualitative semi-structured interviews were conducted to obtain a comprehensive understanding of local participants' perceptions of the impacts of the establishment of NRs. Such observations could provide important evidence for conservation and potentially improve conservation practice and outcomes. This study used a modified sustainable livelihoods framework to analyze livelihood changes and strategies conducted in the process of NR establishment. Based on different capitals, this framework helped to explore the changes occurring with different aspects of livelihoods and associated adaptation strategies. The framework could be applied in broader circumstances to assess livelihoods or welfare changes, not only in NRs, but also other livelihood or development-related projects.

In JBR, local residents realized the importance of biological conservation, as they could directly foresee its benefits in relation to development. In contrast, conservation strategies did not directly enhance local people's livelihoods in SNNR, and also limited the use of natural resources and local development. People in SNNR did not actively participate in conservation, as conservation was seen only as a government priority, whereas the local people wanted to pursue better living conditions. Tourism development in SNNR did not directly involve people who lived within SNNR boundaries; as a result, they have less chance to get benefits from tourism. Tourism seems to provide a good livelihoods option to strengthen livelihoods capital with minimum environmental impacts in both cases. However, involvement in tourism requires an ideal geographical location and sufficient capitals: not only financial and natural capital, but also physical, social, and human capitals, and most rural villagers usually do not possess these. Current conservation policies usually make insufficient provisions for alternative livelihoods and lack incentives that would encourage local people to participate in conservation-related activities. A broader array of policies, including infrastructure development, the development of the market economy, and improvements to the employment market, are critical for improving conservation outcomes. This will require multi-sector and multi-scale cooperation in order to not only to strengthen cooperation among PA-related governmental departments, but also other stakeholders, including non-governmental institutions and local communities. A more synthetic plan needs to be brought forward instead of multiple and sometimes even contradictory plans made by different departments. This new, more holistic approach should consider the interests of local residents and offer alternative livelihood strategies to help local people adapt to the new strategies.

Author Contributions: W.W., R.K. and J.L.I. designed the study; W.W., M.J. and J.L. conducted the field work and collected the data; W.W. and M.J. analyzed the data; W.W. wrote the paper; R.K., J.L. and J.L.I. contributed to reviewing and editing the paper.

Funding: This work was supported by the National Natural Science Foundation of China [71673288], Renmin University Science Research Foundation [2015030223], the China Scholarship Council [201308180001], Rufford Small Grant [19593-1], and the Mitacs Globalink Research Award [IT06452].

Acknowledgments: This research has been approved by the UBC Behavioral Research Ethics Board [H15-02417]. Many thanks to staffs in Sichuan Forestry Administration, Jiuzhaigou Management Administration and Shennongjia Nature Reserve Management Administration for their support during the field work and data collection. We also want to thank three anonymous reviewers for their valuable suggestions.

Conflicts of Interest: The authors declare no conflict of interest.

\section{References}

1. Ghimire, K.B. Conservation and Social Development: An Assessment of Wolong and Other Panda Reserves in China, December 1994. United Nations Research Institute for Social Development. Available online: http:/ / www.unrisd.org/80256B3C005BCCF9/search/1EFDA7316F15F7D180256B67005B66B9? OpenDocument (accessed on 26 May 2016). 
2. Brüggemann, J. National parks and protected area management in Costa Rica and Germany: A comparative analysis. In Social Change \& Conservation; Ghimire, B.K., Pimbert, P.M., Eds.; Earthscan Publications Limited: London, UK, 1997.

3. Ministry of Environmental Protection of China. Available online: http://www.zhb.gov.cn/stbh/zrbhq/ qgzrbhqml/ (accessed on 26 January 2017).

4. Zhou, D.Q.; Edward Grumbine, R. National parks in China: Experiments with protecting nature and human livelihoods in Yunnan province, Peoples' Republic of China (PRC). Biol. Conserv. 2011, 144, 1314-1321. [CrossRef]

5. Zhou, D.; Wang, Z.; Lassoie, J.; Wang, X.; Sun, L. Changing stakeholder relationships in nature reserve management: A case study on Snake Island-Laotie Mountain National Nature Reserve, Liaoning, China. J. Environ. Manag. 2014, 146, 292-302. [CrossRef] [PubMed]

6. The Regulation on Nature Reserves. No. 18; 1994. Available online: http://www.gov.cn/gongbao/content/ 2011/content_1860776.htm (accessed on 20 March 2016).

7. Buckley, R.; Cater, C.; Zhong, L.S.; Tian, C. Shengtai luyou: Cross-Cultural Comparison in Ecotourism. Ann. Tour. Res. 2008, 35, 945-968. [CrossRef]

8. Li, W.; Ge, X.; Liu, C. Hiking trails and tourism impact assessment in protected area: Jiuzhaigou Biosphere Reserve, China. Environ. Monit. Assess. 2005, 108, 279-293. [CrossRef] [PubMed]

9. Krüger, O. The role of ecotourism in conservation: Panacea or Pandora's box? Biodivers. Conserv. 2005, 14, 579-600. [CrossRef]

10. Li, W.; Zhang, Q.; Liu, C.; Xue, Q. Tourism's impacts on natural resources: A positive case from China. Environ. Manag. 2006, 38, 572-579. [CrossRef] [PubMed]

11. Tao, T.C.H.; Wall, G. Tourism as a sustainable livelihood strategy. Tour. Manag. 2009, 30, 90-98. [CrossRef]

12. Bennett, N.J.; Dearden, P. Why local people do not support conservation: Community perceptions of marine protected area livelihood impacts, governance and management in Thailand. Mar. Policy 2014, 44, 107-116. [CrossRef]

13. Cruz, R.E.H.; Baltazar, E.B.; Gomez, G.M.; Lugo, E.I.E. Social adaptation: Ecotourism in the Lacandon forest. Ann. Tour. Res. 2005, 32, 610-627. [CrossRef]

14. Jones, S. Community-based ecotourism: The significance of social capital. Ann. Tour. Res. 2005, 32, 303-324. [CrossRef]

15. Nepal, S.K. Tourism and rural settlements Nepal's Annapurna region. Ann. Tour. Res. 2007, 34, 855-875. [CrossRef]

16. Weaver, D.B.; Lawton, L.J. Twenty years on: The state of contemporary ecotourism research. Tour. Manag. 2007, 28, 1168-1179. [CrossRef]

17. Kulig, A.; Kolfoort, H.; Hoekstra, R. The case for the hybrid capital approach for the measurement of the walfare and sustainability. Ecol. Indic. 2010, 10, 118-128. [CrossRef]

18. World Bank. Where Is the Wealth of Nations? World Bank: Washington, DC, USA, 2006. Available online: http: / / siteresources.worldbank.org/INTEEI/214578-1110886258964/20748034/All.pdf (accessed on 26 May 2016).

19. Report of the World Commission on Environment Development, Our Common Future; Oxford University Press: Oxford, UK, 1987. Available online: http:/ / www.un-documents.net/our-common-future.pdf (accessed on 14 December 2016).

20. Ekins, P.; Dresner, S.; Dahlström, K. The Four-Capital Method of Sustainable Development Evaluation. Eur. Enviorn. 2008, 18, 63-80. [CrossRef]

21. Goodwin, N.R. Five Kinds of Capital: Useful Concepts for Sustainable Development. Global Development and Environment Institute Working Paper No. 03-07. 2003. Available online: https:/ /ageconsearch.umn. edu/bitstream/15595/1/wp030007.pdf (accessed on 14 December 2016).

22. Maack, M.; Davidsdottir, B. Five capital impact assessment: Appraisal framework based on theory of sustainable well-being. Renew. Sustain. Energy Rev. 2015, 50, 1338-1351. [CrossRef]

23. Bourdieu, P. Chapter 6: The forms of capital. In Cultural Theory: An Anthology; Wiley: Hoboken, NJ, USA, 1986; pp. 81-93.

24. Department for International Development (DFID). Sustainable Livelihoods Guidance Sheets; DFID: London, UK, 1999; Available online: http:/ / doi.org/10.1002/smj (accessed on 20 April 2015).

25. Atkinson, G.; Hamilton, K. Savings, growth and the resource curse hypothesis. World Dev. 2003, 31, 1793-1807. [CrossRef] 
26. Pearce, D.W.; Atkinson, G.D. Capital theory and the measurement of sustainable development: An indicator of "weak" sustainability. Ecol. Econ. 1993, 8, 103-108. [CrossRef]

27. Victor, P.A. Indicators of sustainable development: Some lessons from capital theory. Ecol. Econ. 1991, 4, 191-213. [CrossRef]

28. Scoones, I. Sustainable Rural Livelihoods: A Framework for Analysis; IDS Working Paper 72; IDS: Brighton, UK, 1998.

29. United Nations Educational, Scientific and Cultural Organization. Jiuzhaigou Valley Scenic and Historic Interest Area. Available online: http:/ / whc.unesco.org/en/list/637 (accessed on 23 March 2016).

30. Li, W. Chapter 5: Tourism, Local Community and Natural Resources: Tourism Impact Assessment and Tourism Management Analysis in the Jiuzhaigou Biosphere Reserve, China. In Ecotourism and Environmental Sustainability: Principles and Practice; Hill, J., Gale, T., Eds.; MPG Book Ltd.: Bodmin, UK, 2009; pp. $73-88$.

31. United Nations Educational, Scientific and Cultural Organization. Available online: http://whc.unesco.org/ en/tentativelists /104/ (accessed on 20 May 2016).

32. Borges, M.A.; Carbone, G.; Bushell, R.; Jaeger, T. Sustainable Tourism and Natural World Heritage: Priorities for Action. IUCN, 2011. Available online: https://www.iucn.org/content/sustainable-tourism-and-naturalworld-heritage-priorities-action (accessed on 23 March 2016).

33. Chen, Z.; Yang, J.; Xie, Z. Economic development of local communities and biodiversity conservation: A case study from Shennongjia National Nature Reserve, China. Biodivers. Conserv. 2005, 14, 2095-2108. [CrossRef]

34. Xiang, Z.; Yu, Y.; Yang, M.; Yang, J.; Niao, M.; Li, M. Does flagship species tourism benefit conservation? A case study of the golden snub-nosed monkey in Shennongjia National Nature Reserve. Chin. Sci. Bull. 2011, 56, 2553-2558. [CrossRef]

35. Shennongjia Report; Unpublished work; 2014.

36. Su, M.M.; Wall, G.; Jin, M. Island livelihoods: Tourism and fishing at Long Islands, Shandong Province, China. Ocean Coast. Manag. 2016, 122, 20-29. [CrossRef]

37. Vedeld, P.; Jumane, A.; Wapalila, G.; Songorwa, A. Protected areas, poverty and conflicts. A livelihood case study of Mikumi National Park, Tanzania. For. Policy Econ. 2012, 20, 20-31. [CrossRef]

38. West, P.; Igoe, J.; Brockington, D. Parks and Peoples: The Social Impact of Protected Areas. Ann. Rev. Anthropol. 2006, 35, 251-277. [CrossRef]

39. Lindsey, P.A.; Nyirenda, V.R.; Barnes, J.I.; Becker, M.S.; McRobb, R.; Tambling, C.J.; Taylor, W.A.; Watson, F.G.; $\mathrm{t}^{\prime}$ Sas-Rolfes, M. Underperformance of African protected area networks and the case for new conservation models: Insights from Zambia. PLoS ONE 2014, 9, e94109. [CrossRef] [PubMed]

40. Munanura, I.E.; Backman, K.F.; Hallo, J.C.; Powell, R.B. Perceptions of tourism revenue sharing impacts on Volcanoes National Park, Rwanda: A Sustainable Livelihoods framework. J. Sustain. Tour. 2016, 24, 1709-1726. [CrossRef]

41. Bebbington, A. Capitals and Capabilities: A Framework for Analyzing Peasant Viability, Rural Livelihoods and Poverty. World Dev. 1999, 27, 2021-2044. [CrossRef]

42. Schmidt-Soltau, K.; Brockington, D. Protected Areas and Resettlement: What Scope for Voluntary Relocation? World Dev. 2007, 35, 2182-2202. [CrossRef]

(C) 2018 by the authors. Licensee MDPI, Basel, Switzerland. This article is an open access article distributed under the terms and conditions of the Creative Commons Attribution (CC BY) license (http:// creativecommons.org/licenses/by/4.0/). 